\title{
Ograniczony krąg uczestników w postępowaniu wieczystoksięgowym a realizacja prawa do sądu
}

\author{
A limited group of participants in land and mortgage register proceedings \\ and the exercise of the right to court \\ Ограниченный круг участников производства по регистрации прав \\ на недвижимость а реализация права на суд
}

\author{
EMIL STEFAN KOWALIK \\ Dr, Katolicki Uniwersytet Lubelski Jana Pawła II \\ e-mail: emilkowalik82@gmail.com, https://orcid.org/0000-0003-1839-3925
}

\begin{abstract}
Streszczenie: Odpowiednio ukształtowane relacje pomiędzy organami państwa a obywatelem oraz pomiędzy obywatelami mają bezpośrednie przełożenie na prawidłowe funkcjonowanie organizmu państwowego. Często podnoszony jest zarzut, że wyrażony w art. $626^{1} \S 2$ Kodeksu postępowania cywilnego ograniczony krąg uczestników postępowania wieczystoksięgowego oraz wywodzący się z art. $626^{8} \S 2$ K.p.c. ograniczony zakres kognicji sądu w tym postępowaniu narusza konstytucyjną zasadę prawa do sądu. Przedmiotem zainteresowania autora artykułu jest wpływ ograniczonego kręgu uczestników w postępowaniu wieczystoksięgowym na zapewnienie podmiotom uczestniczącym na rynku nieruchomości prawa do sądu i gwarancji rzetelnego prowadzenia postępowania przed nim.
\end{abstract}

Słowa kluczowe: księgi wieczyste, postępowanie wieczystoksięgowe, uczestnik postępowania, prawo do sądu, Konstytucja RP

Summary: Properly shaped relations between state bodies and citizens as well as between citizens have a direct impact on the proper function of the state as an organism. The objection is often raised that, expressed in Art. $626^{1} \S 2$ of the Code of Civil Procedure, a limited group of participants in land and mortgage register proceedings and derived from art. $626^{8} \S 2$ of the Code of Civil Procedure limited the scope of the court's jurisdiction in these proceedings violate the constitutional principle of the right to a fair trial. The subject of this article is the discussion of the influence of a limited group of participants in the land and mortgage register proceedings to provide entities participating in the real estate market with the right to a court and guarantees of fair conduct of proceedings before him.

Key words: land and mortgage registers, land and mortgage register proceedings, participant in proceedings, the right to a court, the Constitution

Резюме: Правильно сформированные отношения между государственными органами и гражданами и между гражданами оказывают непосредственное влияние на надлежащее функционирование государства. Часто утверждается, что ограниченный круг участников производства по регистрации прав на недвижимость, выраженный в статье 626 § 2 Гражданского процессуального кодекса, и ограниченный объем когниции суда в этих разбирательствах, вытекающий из статьи $626^{8} \S 2$ Гражданского процессуального кодекса, нарушают конституционный принцип права на суд. Предметом, рассматриваемым автором, является вопрос о влиянии ограниченного круга участников производства по регистрации прав на недвижимость на обеспечение субъектам рынка недвижимости права на суд и гарантии надежного судебного производства.

Ключевые слова: земельно-кадастровая книга, производство по регистрации прав на недвижимость, участник производства, право на суд, Конституция Республики Польша 


\section{Wstęp}

Prawo do sądu jest jednym z podstawowych praw przysługujących jednostce $\mathrm{w}$ demokratycznym państwie prawa, w którym prawo stanowione jest podstawą wszelkich działań organów państwowych, w tym także tych podejmowanych w stosunku do jednostki ${ }^{1}$. Zapewnia ono dostęp do wszelkich konstytucyjnie ustanowionych sądów oraz gwarantuje rzetelne prowadzenie postępowania przed nimi, bez możliwości zamknięcia drogi sądowej dochodzenia naruszonych wolności lub praw. Odpowiednio ukształtowane relacje pomiędzy organami państwa a obywatelem oraz pomiędzy obywatelami mają bezpośrednie przełożenie na prawidłowe funkcjonowanie organizmu państwowego. Państwo odgrywa tutaj kluczową rolę, gdyż to do niego należy stworzenie odpowiednich warunków instytucjonalnych oraz prawnych dla zapewnienia ochrony praw i wolności ${ }^{2}$.

Prawo własności, w tym własności nieruchomości, stanowi jedną z najważniejszych wartości, których ochrona leży w interesie państwa. Dla prawidłowego funkcjonowania obrotu nieruchomościami istotny staje się odpowiednio ukształtowany system rejestracji nieruchomości oraz czynności z nimi związanymi, oparty na systemie ksiąg wieczystych, których treść może determinować określone uprawnienia $^{3}$. Zgodnie $\mathrm{z}$ art. 1 ust. 1 i 3 ustawy z dnia 6 lipca 1982 r. o księgach wieczystych i hipotece $e^{4}$ księgi wieczyste prowadzi się $\mathrm{w}$ celu ustalenia stanu prawnego nieruchomości oraz spółdzielczego własnościowego prawa do lokalu. Tak ukształtowany ustrój ksiąg wieczystych ma szczególne znaczenie w kontekście zapewnienia bezpieczeństwa obrotu prawnego nieruchomościami ${ }^{5}$.

Powyższe uwagi prowadzą do wniosku, że postępowanie wieczystoksięgowe regulowane w rozdziale 6 dziale III tytule II księgi drugiej ustawy z dnia 17 listo-

1 B. Banaszak, Prawo konstytucyjne, Warszawa 2008, s. 221-223.

2 P. Grzegorczyk, K. Weitz, w: Konstytucja RP, t. 1. Komentarz do art. 1-86, red. M. Safian, L. Bosek, Warszawa 2016, s. 217-218 i 1776-1780; P. Tuleja, w: Konstytucja Rzeczpospolitej Polskiej. Komentarz, red. P. Tuleja, Warszawa 2019, s. 160-163; M. Florczak-Wątor, w: Konstytucja Rzeczpospolitej Polskiej. Komentarz, red. Tuleja, Warszawa 2019, s. 256-257.

3 T. Stawecki, Rejestr nieruchomości, księgi hipoteczne, księgi wieczyste od czasów najdawniejszych do XXI wieku, Studia Iuridica 2002, nr 40, s. 168; Z.K. Nowakowski, Prawo rzeczowe. Zarys wykładu, Warszawa 1969, s. 219; J. Kuropatwiński, Księgi wieczyste: komentarz do art. 1-58 ${ }^{2}$ u.k.w.h. oraz art. $626^{1}-626^{13}$ k.p.c., t. 1. Komentarz do art. 1-10 ustawy o ksiegach wieczystych i hipotece, Bydgoszcz 2013, s. 19.

4 Ustawa z dnia 6 lipca 1982 r. o księgach wieczystych i hipotece, tekst jednolity: Dz. U. z 2019 r. poz. 2204 z późn. zm. (dalej: u.k.w.h.).

5 E. Kowalik, Zakres kognicji sądu w postępowaniu wieczystoksiegowym, Warszawa 2020, s. 18-19. 
pada 1964 r. - Kodeks postępowania cywilnego ${ }^{6}$ służy realizacji materialnoprawnych przepisów prawa rzeczowego w zakresie stosunków majątkowych uczestników obrotu prawnego nieruchomościami, w szczególności osób posiadających prawa do nieruchomości. Istotne staje się zatem rozstrzygnięcie, czy ograniczony krąg uczestników postępowania wieczystoksięgowego wyrażony w art. $626^{1} \S 2$ K.p.c. zapewnia w pełni konstytucyjne prawo do sądu podmiotom działającym na rynku nieruchomości.

W niniejszym artykule poddano analizie realizację prawa do sądu, wyrażonego w Konstytucji Rzeczypospolitej Polskiej z dnia 2 kwietnia 1997 r.7 i w Europejskiej konwencji o ochronie praw człowieka i podstawowych wolności z dnia 4 listopada $1950 \mathrm{r}^{8}$, na gruncie przepisów materialnych i procesowych regulujących ustrój ksiąg wieczystych. Celem opracowania jest analiza wybranych problemów praktycznych postępowania wieczystoksięgowego i próba przedstawienia propozycji ich rozwiązania w kontekście zapewnienia uczestnikom obrotu prawnego nieruchomościami dostępu do sądu wieczystoksięgowego. W pierwszej kolejności odniesiono się do podstawowych elementów prawa do sądu. Następnie opisano kwestię ograniczonego kręgu uczestników postępowania wieczystoksięgowego. W końcu przedstawiono zagadnienie wpływu ograniczonego kręgu uczestników postępowania wieczystoksięgowego na realizację prawa do sądu podmiotów posiadających prawa do nieruchomości.

\section{Pojęcie prawa do sądu}

Prawo do sądu jest jednym z podstawowych praw osobistych jednostki pełniącym funkcję gwarancyjną względem innych praw i wolności. Stanowi zasadę konstytucyjną, gdyż zawarta jest w akcie o najwyższej mocy prawnej, jakim jest Konstytucja, co oznacza, że wszystkie inne prawa jednostki muszą być z nią zgodne. Prawo do sądu jest prawem autonomicznym ${ }^{9}$, na które składa się zespół mechanizmów gwarancyjnych urzeczywistnionych poprzez określone instytucje prawnoproceso-

6 Ustawa z dnia 17 listopada 1964 r. - Kodeks postępowania cywilnego, tekst jednolity: Dz. U. z 2020 r. poz. $1575 \mathrm{z}$ późn. zm. (dalej: K.p.c.).

7 Konstytucja Rzeczypospolitej Polskiej z dnia 2 kwietnia 1997 r., Dz. U. z 1997 r. Nr 78, poz. 483 z późn. zm. (dalej: Konstytucja).

8 Europejska konwencja o ochronie praw człowieka i podstawowych wolności z dnia 4 listopada 1950 r., Dz. U. z 1993 r. Nr 61, poz. 284 (dalej: Konwencja).

9 Wyrok TK z dnia 10 lipca 2000 r., SK 12/99, OTK ZU 2000, z. 5, poz. 143. 
we podlegające bezpośredniemu stosowaniu, chyba że przepisy Konstytucji stanowią inaczej ${ }^{10}$.

W ustawie zasadniczej prawo do sądu zostało sformułowano expressis verbis $\mathrm{w}$ dwóch aspektach - w materialnym (pozytywnym) ${ }^{11}$ oraz $\mathrm{w}$ formalnym (negatywnym). Pierwszy z nich przejawia się w tym, że: „Każdy ma prawo do sprawiedliwego i jawnego rozpatrzenia sprawy bez nieuzasadnionej zwłoki przez właściwy, niezależny, bezstronny i niezawisły sąd” (art. 45 ust. 1 Konstytucji). Z kolei aspekt negatywny wyrażony w art. 77 ust. 2 Konstytucji oznacza, że: „Ustawa nie może nikomu zamykać drogi sądowej dochodzenia naruszonych wolności lub praw”12.

$\mathrm{Z}$ kolei na gruncie Konwencji prawo do sądu zostało wyartykułowane $\mathrm{w}$ art. 6 ust. 1, zgodnie $\mathrm{z}$ którym

Każdy ma prawo do sprawiedliwego i publicznego rozpatrzenia jego sprawy w rozsądnym terminie przez niezawisły $i$ bezstronny sąd ustanowiony ustawą przy rozstrzyganiu o jego prawach i obowiązkach o charakterze cywilnym albo o zasadności każdego oskarżenia w wytoczonej przeciwko niemu sprawie karnej. Postępowanie przed sądem jest jawne, jednak prawa i publiczność mogą być wyłączone z całości lub części rozprawy sądowej ze względów obyczajowych, z uwagi na porządek publiczny lub bezpieczeństwo państwowe w społeczeństwie demokratycznym, gdy wymaga tego dobro małoletnich lub gdy służy to ochronie życia prywatnego stron albo też w okolicznościach szczególnych, w granicach uznanych przez sąd za bezwzględnie konieczne, kiedy jawność mogłaby przynieść szkodę interesom wymiaru sprawiedliwości ${ }^{13}$.

Analizując treść prawa do sądu, należy zaznaczyć, że zgodnie z utrwalonym orzecznictwem i stanowiskiem doktryny prawo to ma charakter wieloskładnikowy. Trybunał Konstytucyjny w wyroku z dnia 9 czerwca 1998 r. ${ }^{14}$ stwierdził, że

10 M. Żak, Prawo do sadu jako element zasady dobrego rzadzenie w świetle orzecznictwa $z$ zakresu praw człowieka, Palestra 2020, nr 2, s. 74; P. Grzegorczyk, K. Weitz, w: Konstytucja..., s. 217-218 i 1776-1780; P. Tuleja, w: Konstytucja..., s. 160-163; M. Florczak-Wątor, w: Konstytucja..., s. 256-257; P. Pogonowski, Realizacja prawa do sadu w postępowaniu cywilnym, Warszawa 2005, s. 1-6; M. Sawczuk, Konstytucyjne idee prawa sądowego cywilnego, w: Konstytucyjny ustrój państwa. Księa jubileuszowa Profesora Wiesława Skrzydty, red. T. Bojarski, E. Gdulewicz, J. Szraniawski, Lublin 2000, s. 241.

11 M. Florczak-Wątor, Prawo do sądu jako prawo jednostki i jako gwarancja horyzontalnego dziatania praw i wolności, Przegląd Prawa Konstytucyjnego 2016, nr 3, s. 51.

12 P. Grzegorczyk, K. Weitz, w: Konstytucja..., s. 1776-1777 i 1092-1093; M. Florczak-Wątor, w: Konstytucja..., s. 256; P. Tuleja, w: Konstytucja..., 160-163.

13 Por. K. Korzan, Zagadnienia dostosowania polskiego systemu postępowania cywilnego do standardów europejskich, Radca Prawny 1996, nr 5, s. 5-6.

14 Wyrok TK z dnia 9 czerwca 1998 r., K 28/97, OTK ZU 1998, z. 4, poz. 50. 
Na konstytucyjne prawo do sądu składa się w szczególności: 1) prawo dostępu do sądu, tj. prawo uruchomienia procedury przed sądem - organem o określonej charakterystyce (niezależnym, bezstronnym i niezawisłym); 2) prawo do odpowiedniego ukształtowania procedury sądowej, zgodnie z wymogami sprawiedliwości i jawności; 3) prawo do wyroku sądowego, tj. prawo do uzyskania wiążącego rozstrzygnięcia danej sprawy przez sąd ${ }^{15}$.

Za czwarty element składający się na prawo do sądu uznaje się prawo do uzyskania skutecznej egzekucji orzeczenia sądowego ${ }^{16}$. Dodatkowo z punktu widzenia konstytucyjnego prawa dostępu do sądu za kluczowy element omawianego zagadnienia zakłada się standard proporcjonalności opłat i kosztów sądowych ${ }^{17}$.

Przyjmuje się w doktrynie, że prawo do sądu można rozpatrywać w dwóch znaczeniach: zasady konstytucyjnej oraz prawa podmiotowego ${ }^{18}$. Prawo do sądu jako zasada konstytucyjna obejmuje normę prawną skierowaną do organów władzy publicznej nakładającą obowiązek ukształtowania niezależnego, bezstronnego, niezawisłego sądownictwa oraz procesu rozpatrywania spraw ${ }^{19}$. Z kolei prawo do sądu jako konstytucyjne prawo podmiotowe określa się jako chroniony przez prawo interes jednostki stanowiący podstawę roszczenia względem państwa i jego organów ${ }^{20}$.

Taka interpretacja prawa do sądu wskazuje przede wszystkim na jego ochronny charakter. Jednostka ma ustanowione różne gwarancje, których realizacji może żądać od organów władzy państwowej. Wskazać przy tym należy na stanowisko wyrażone w wyroku Trybunału Konstytucyjnego z dnia 10 lipca 2000 r. $^{21}$, gdzie podkreślono, że

Miejsce art. 45 w systematyce konstytucji wskazuje na autonomiczny charakter prawa do sądu. Nie jest ono jedynie instrumentem umożliwiającym wykonywanie innych praw i wolności konstytucyjnych, lecz ma byt samoistny i podlega ochronie niezależnie od naruszenia innych praw podmiotowych.

15 Zob. także wyrok TK z dnia 10 lipca 2000 r., SK 12/99, OTK ZU 2000, z. 5, poz. 143; wyrok TK z dnia 7 lipca 2004 r., P 4/04, OTK ZU 2004, z. 8A, poz. 81; wyrok TK z dnia 16 grudnia 2008 r., P 17/07, Dz. U. z 2008 r. Nr 228, poz. 1524; por. H. Pietrzkowski, Prawo do sqdu (wybrane zagadnienia), Przegląd Sądowy 1999, nr 11-12, s. 5.

16 Tak uznają m.in. M. Jabłoński, S. Jarosz-Żukowska, Prawa człowieka i systemy ich ochrony. Zarys wykładu, Warszawa 2010, s. 133.

17 Zob. wyrok TK z dnia 24 lutego 2003 r., K 28/02, OTK ZU 2003, z. 2, poz. 13.

18 Z. Czeszejko-Sochacki, Prawo do sądu w świetle Konstytucji Rzeczypospolitej Polskiej (Ogólna charakterystyka), Państwo i Prawo 1997, z. 11-12 (621-622), s. 89.

19 D. Lis-Staranowicz, Konstytucyjne środki ochrony wolności i praw, w: Wolności i prawa człowieka w Konstytucji Rzeczypospolitej Polskiej, red. M. Chmaj, Warszawa 2016, s. 240; M. Żak, Prawo do sqadu..., s. 75.

20 D. Lis-Staranowicz, Konstytucyjne..., s. 241; M. Żak, Prawo do sqdu..., s. 75, a także wyrok TK z dnia 13 stycznia 2015 r., SK 34/12, OTK ZU, 2015, z. 1A, poz. 9.

21 Wyrok TK z dnia 10 lipca 2000 r., SK 12/99, OTK ZU 2000, z. 5, poz. 143. 
Naruszenie prawa do sądu może mieć przy tym charakter bezpośredni (ujęcie szerokie) lub pośredni (ujęcie wąskie). W szerokim ujęciu prawo do rzetelnego procesu sądowego i merytorycznego rozpatrzenia sprawy jest traktowane jako samodzielny przedmiot ochrony. Naruszenie prawa do sądu sprowadza się zatem do złamania fundamentalnych gwarancji procesowych. W zaistniałej sytuacji prawo do sądu i jego naruszenia rozpatruje się z punktu widzenia kryteriów sprawiedliwości proceduralnej. Na jej istotę zgodnie $\mathrm{z}$ ugruntowanym orzecznictwem składają się następujące ściśle ze sobą powiązane uprawnienia: prawo do wysłuchania; prawo do informowania; obowiązek sądu zbadania wszystkich istotnych aspektów danej sprawy (rozpoznania istoty sprawy); obowiązek ujawnienia w sposób jasny, rzeczowy, klarowny, czytelny toku rozumowania sądu w celu stworzenia adresatowi orzeczenia (decyzji prawnej) możliwości weryfikacji argumentacji przedstawionej w jego uzasadnieniu; przejrzyste zaprezentowanie motywów rozstrzygnięcia sądowego (tzw. rzetelne uzasadnienie); unikanie arbitralności, w szczególności poprzez oparcie procedury prawnej na zasadzie jawności postępowania, równości stron i zapewnieniu udziału zainteresowanych podmiotów w postępowaniu sądowym; zapewnienie przewidywalności rozstrzygnięcia sądowego i spójności działania systemu (wymiaru) sprawiedliwości ${ }^{22}$.

Wąsko rozumiane naruszenie prawa do sądu ma charakter pośredni (refleksowy) i jest rozpatrywane $\mathrm{w}$ kontekście naruszenia innych praw podmiotowych. Sposób interpretacji prawa do sądu kształtuje się sytuacyjnie, jest uzależniony od pozycji procesowej i treści konkretnych uchybień proceduralnych ${ }^{23}$.

Poruszona powyżej problematyka wskazuje na niezwykle doniosłe znaczenie prawa do sądu. To, czy to prawo jest należycie przestrzegane, ma bezpośrednio przełożenie na funkcjonowanie państwa i ma swoje odzwierciedlenie w ustawodawstwie oraz $\mathrm{w}$ procesie stosowania prawa.

\section{Ograniczony krąg uczestników w postępowaniu wieczystoksięgowym}

Zgodnie $\mathrm{z}$ art. $626^{1} \S 2$ K.p.c. uczestnikami postępowania wieczystoksięgowego oprócz wnioskodawcy są tylko te osoby, których prawa zostały wykreślone lub ob-

22 Zob. np. wyrok TK z dnia 20 lipca 2004 r., SK 19/02, OTK ZU 2004, z. 7A, poz. 67; wyrok TK z dnia 31 stycznia 2005 r., SK 27/03, OTK ZU 2005, z. 1A, poz. 8; wyrok TK z dnia 16 stycznia 2006 r., SK 30/05, OTK ZU 2006, z. 1A, poz. 2; wyrok TK z dnia 26 lutego 2008 r., SK 89/06, OTK ZU 2008, z. 1 A, poz. 7 .

M. Żak, Prawo do sądu..., s. 77. 
ciążone bądź na rzecz których wpis ma nastąpić. Z kolei wniosek o wpis może złożyć właściciel nieruchomości, użytkownik wieczysty, osoba, na rzecz której wpis ma nastąpić, albo wierzyciel, jeżeli przysługuje mu prawo, które może być wpisane w księdze wieczystej. W sprawach dotyczących obciążeń powstałych z mocy ustawy wniosek może złożyć uprawniony organ (po $\$ 5$. Powyższe przepisy determinują ograniczony krąg uczestników postępowania wieczystoksięgowego.

Przepis art. $626^{1} \$ 2$ K.p.c. jest przepisem szczególnym w stosunku do art. 510 $\$ 1$ K.p.c., określającym krąg uczestników postępowania nieprocesowego. W doktrynie ugruntowane zostało stanowisko, zgodnie z którym art. $626^{1} \$ 2$ K.p.c. w sposób wyczerpujący wymienia uczestników postępowania wieczystoksięgowego. Pogląd ten uzasadniony jest wykładnią językową art. $626^{1} \$ 2$ K.p.c. poprzez użycie słowa „tylko", jak również celowościową tego przepisu. Postępowanie wieczystoksięgowe ma służyć szybkiemu i sprawnemu ujawnieniu zmiany stanu prawnego nieruchomości, a nieograniczona liczba uczestników, mogących zgłaszać swój udział w postępowaniu, znacznie oddalałyby od zamierzonego przez ustawodawcę celu ${ }^{24}$.

Ograniczony krąg uczestników postępowania wieczystoksięgowego jest konsekwencją zawężonej kognicji sądu w postępowaniu wieczystoksięgowym. Zgodnie $z$ art. $626^{8} \$ 2$ K.p.c. sąd przy rozpoznawaniu wniosku o wpis co do zasady powinien ograniczyć swoje badanie do treści i formy wniosku oraz dołączonych do niego dokumentów, a także treści księgi wieczystej. Trafne jest zatem stwierdzenie, że wobec faktu, iż sąd może rozpoznać tylko określoną kategorię zarzutów i nie rozstrzyga sporów co do prawa, to udział w postępowaniu wieczystoksięgowym szerokiego kręgu podmiotów o różnych interesach byłby niecelowy ${ }^{25}$.

Istotne różnice dotyczące kwalifikacji danego podmiotu jako uczestnika w postępowaniu wieczystoksięgowym związane są z tym, że w postępowaniu tym nie

24 Zob. m.in. postanowienie SN z dnia 16 czerwca 2004 r., I CZ 48/2004, LEX nr 132562; uchwałę SN z dnia 7 lipca 2010 r., III CZP 45/2010, LEX nr 584620, z glosą krytyczną M. Rzewuskiego, Glosa do uchwały SN z 7 lipca 2010 r., III CZP 45/10, Orzecznictwo Sądów Polskich 2011, z. 10, poz. 107 oraz glosą aprobującą J. Szewczyka, Krąg uczestników postępowania wieczystoksięgowego art. $626^{1}$ S 2 k.p.c. Glosa do uchwały SN - Izby Cywilnej z 7 lipca 2010 r. (III CZP 45/10), Monitor Prawa Bankowego 2012, nr 3, s. 30 i nn.; postanowienie SN z dnia 23 sierpnia 2012 r., II CSK 49/2012, LEX nr 1228586, a w doktrynie: E. Gniewek, Wnioskodawca i uczestnicy postępowanie wieczystoksięowego, Rejent 2005, nr 9, s. 73 i nn.; P. Mysiak, Postępowanie wieczystoksięgowe, Warszawa 2012, s. 105; J. Zawadzka, w: Ustawa o księgach wieczystych i hipotece. Postępowanie wieczystoksieggowe, red. J. Pisuliński, Warszawa 2014, s. 1163, 1164; E. Gniewek, Ksiegi wieczyste: art. 1-58 ${ }^{2}$ KWU, art. $626^{1}-626^{13}$ KPC. Komentarz, Warszawa 2018, s. 786-787; P. Pruś, w: Kodeks postępowania cywilnego. Komentarz, t. 2. Art. 506-1217, red. M. Manowska, Warszawa 2021, s. 623-624.

25 Zob. m.in. postanowienie SN z dnia 16 czerwca 2004 r., I CZ 48/2004, LEX nr 132562 oraz postanowienie SN z dnia 20 stycznia 2011 r., I CSK 185/2010, LEX nr 848107; tak też E. Gniewek, Wnioskodawca..., s. 74-75; E. Gniewek, Księgi..., s. 787-788 oraz J. Zawadzka, Ustawa..., s. 1163-1164. 
podlega zastosowaniu art. $510 \$ 2$ zd. 1 i 2 K.p.c. Sąd wieczystoksięgowy nie wzywa zatem do udziału w sprawie uczestnika postępowania, jak również nie wydaje żadnego orzeczenia w przedmiocie dopuszczenia albo odmowy dopuszczenia do udziału w postępowaniu. Konsekwencją braku zastosowania powyższego przepisu jest funkcjonowanie w praktyce wieczystoksięgowej zasady doręczania zawiadomień i odpisów postanowień o odmowie wpisu tylko uczestnikom postępowania. Wyrazem odmowy uznania podmiotu za uczestnika postępowania jest pominięcie go przy doręczeniach. Należy zgodzić się z postanowieniem Sądu Najwyższego $\mathrm{z}$ dnia 21 lutego $2007 \mathrm{r}^{26}$, zgodnie $\mathrm{z}$ którym mylne doręczenie przez sąd wieczystoksięgowy zawiadomienia o wpisie podmiotowi nienależącemu w świetle art. $626^{1}$ $\$ 2$ K.p.c. do kręgu uczestników postępowania wieczystoksięgowego nie powoduje, że podmiot ten staje się uczestnikiem tego postępowania ${ }^{27}$. Podobnie wskazanie we wniosku o wpis osoby, która nie należy do powyższego kręgu, nie oznacza, że uzyskała ona prawo do zaskarżenia tego orzeczenia, nawet gdy doręczono jej zawiadomienie o wpisie, podstawowym bowiem warunkiem dopuszczalności tego środka zaskarżenia jest legitymowanie się uprawnieniem do uczestniczenia w postępowaniu ${ }^{28}$.

Należy zgodzić się z przedstawicielami doktryny odrzucającymi wykładnię literalną art. $626^{1} \$ 2$ K.p.c. wobec jego mylnej redakcji zakładającej, że przymiot uczestnika postępowania podmioty w nim wskazane uzyskują dopiero po wydaniu orzeczenia (wpisie). Słusznie wykładnia celowościowa i systemowa wskazuje, że uczestnikami postępowania $\mathrm{w}$ świetle art. $626^{1} \$ 2$ K.p.c. będą nie tylko osoby, których prawa zostały wykreślone lub obciążone w wyniku dokonania wpisu, co wprost wynika z przepisu, ale za uczestników postępowania wieczystoksięgowego uznać należy również osoby, których prawa w świetle treści wniosku albo z punktu widzenia przedmiotu postępowania wszczętego z urzędu miałyby zostać wykreślone lub obciążone. Taka interpretacja uzasadnia przyznanie tym osobom prawa udziału w postępowaniu na etapie badania formalnego wniosku (wszczęcia z urzędu) jeszcze przed jego merytorycznym rozpoznaniem i niezależnie od sposobu jego rozstrzygnięcia ${ }^{29}$.

26 Postanowienie SN z dnia 21 lutego 2007 r., I CZ 138/2006, LEX nr 274231 oraz postanowienie SN z dnia 3 kwietnia 2014 r., V CZ 18/14, LEX nr 1463430

27 B. Łopalewski, Krąg uczestników postępowania wieczystoksięgowego - w poszukiwaniu optymalnego modelu (uwagi de lage lata), Rejent 2012, nr 1, s. 83; J. Zawadzka, Ustawa..., s. 1164.

28 Postanowienie SN z dnia 31 stycznia 2017 r., I CSK 612/16, LEX nr 2254804; E. Gniewek, Ksiegi..., s. 786.

29 Tak trafnie P. Mysiak, Postępowanie..., s. 107; B. Łopalewski, Krąg..., s. 83; J. Szewczyk, Krąg uczestników..., s. 36; E. Gniewek, Księgi..., s. 786-787. 
Zgodnie z art. art. $626^{8} \$ 7$ K.p.c. wpisem w księdze wieczystej jest również wykreślenie. Prowadzi to do wniosku, że uczestnikiem postępowania wieczystoksięgowego jest nie tylko osoba, na której rzecz ma być dokonany wpis w księdze wieczystej, ale również osoba, na rzecz której ma nastąpić wykreślenie. Wobec czego oprócz osoby, której przysługiwały prawa podlegające wykreśleniu, uczestnikami będą także osoby, których prawa były tymi prawami obciążone, gdyż to „na ich rzecz" następuje wykreślenie ${ }^{30}$.

Osoby, do których odnosi się art. $626^{1} \$ 2$ K.p.c., są uczestnikami postępowania wieczystoksięgowego ex lege od momentu jego wszczęcia ${ }^{31}$. Jak jednak przyjmuje Sąd Najwyższy w uzasadnieniu do uchwały składu siedmiu sędziów z dnia 20 kwietnia 2010 r. $^{32}$, także w wypadkach, w których przymiot uczestnika postępowania wynika wprost z ustawy, konieczny jest akt procesowy podnoszący dany podmiot do roli uczestnika postępowania. Mając powyższe na uwadze, uczestnikiem postępowania wieczystoksięgowego będzie tylko ta osoba spośród określonych w art. $626^{1}$ $\$ 2$ K.p.c., występująca w danym postępowaniu na wskutek wskazania jej przez wnioskodawcę lub też $\mathrm{w}$ razie wzięcia udziału w postępowaniu w wyniku własnej inicjatywy wobec doręczenia jej przez sąd zawiadomienia o wpisie, odpisu postanowienia o oddaleniu wniosku o wpis lub innego orzeczenia zapadłego w toku postępowania $^{33}$.

\section{Realizacja prawa do sądu w postępowaniu wieczystoksięgowym w kontekście ochrony praw podmiotów posiadających prawa do nieruchomości}

Postępowanie wieczystoksięgowe w sposób szczególny realizuje prawo do sądu rozumiane jako prawo podmiotu do uzyskania ochrony prawnej. Spowodowane jest to treścią art. $626^{1} \$ 2$ K.p.c., który określa wyczerpująco krąg uczestników postępowania wieczystoksięgowego, stanowiącego lex specialis w stosunku do art. 510 $\S 1$ K.p.c., wyłączając tym samym jego stosowanie w postępowaniu wieczystoksię-

30 J. Zawadzka, Ustawa..., s. 1166; E. Gniewek, Ksiegi..., s. 788-789; P. Pruś, Kodeks..., s. 623.

31 Tak E. Gniewek, Wnioskodawca..., Rejent 2005, nr 9, s. 78; E. Jefimko, Postępowanie wieczystoksięgowe jako szczególny rodzaj postępowania nieprocesowego (zagadnienia wybrane), Przegląd Sądowy 2002, nr 10, s. 62; P. Mysiak, Podmioty postępowania wieczystoksieggowego, Rejent 2007, nr 4, s. 55; P. Mysiak, Postępowanie..., s. 107; B. Łopalewski, Krag..., s. 82-83.

32 Uchwała SN z dnia 20 kwietnia 2010 r., III CZP 112/2009, LEX nr 570265,

33 Por. wyrok SN z dnia 10 lipca 1997 r., I CZ 82/97, LEX nr 31152; J. Zawadzka, Ustawa ..., s. 1166. 
gowym. Ograniczony krąg uczestników postępowania wieczystoksięgowego nie pozostaje bez wpływu na szybkość i sprawność procesu poprzez ujawnianie przez wpis w księdze wieczystej stanu prawnego nieruchomości. Z drugiej strony ograniczona kognicja sądu wieczystoksięgowego oraz zawężony krąg uczestników postępowania sprawia, że pewna grupa podmiotów ma utrudniony bądź wręcz wyłączony dostęp do sądu wieczystoksięgowego. Ma to miejsce w sytuacjach, w których ujawniony w księdze wieczystej stan prawny nieruchomości nie jest zgodny z rzeczywistym stanem prawnym. Powstaje wówczas wątpliwość, czy krąg uczestników postępowania powinien być ustalany według treści aktualnych wpisów w księdze wieczystej, czy też należy uwzględniać rzeczywisty stan prawny nieruchomości ${ }^{34}$.

Zgodnie $\mathrm{z}$ utrwalonym poglądem treść wpisu ostrzeżenia zawiera się w pojęciu „treści księgi wieczystej”, którą sąd bierze pod uwagę przy rozpatrywaniu wniosku o wpis. Zatem sądowi wieczystoksięgowemu znany jest właściciel nieruchomości, jeśli w księdze wieczystej uprzednio wpisano ostrzeżenie, że stan prawny nieruchomości ujawniony w księdze wieczystej stał się niezgodny z rzeczywistym stanem prawnym $\mathrm{w}$ wyniku zmiany osoby właściciela. Wiedzę na temat rzeczywistego właściciela nieruchomości sąd wieczystoksięgowy może powziąć również z innych źródeł, np. zawiadomienia organu państwowego o zmianie właściciela (art. 36 ust. 1 u.k.w.h.), stanowiącego podstawę do wpisania $\mathrm{z}$ urzędu ostrzeżenia o niezgodności ujawnionego $\mathrm{w}$ niej stanu prawnego $\mathrm{z}$ rzeczywistym stanem prawnym, lub samodzielne zgłoszenie się rzeczywistego właściciela nieruchomości składającego skargę na orzeczenie referendarza sądowego ${ }^{35}$.

Sąd wieczystoksięgowy z uwagi na swoją ograniczoną kognicję nie może rozstrzygać sporów o prawa, dlatego też każde zgłoszenie się właściciela nieruchomości powinno być stosownie udokumentowane. Zgłoszenie się uczestnika i wykazanie przysługującego mu prawa własności bez wniosku o ujawnienie jego prawa w księdze wieczystej powinno zgodnie $\mathrm{z}$ art. $626^{13} \$ 1$ K.p.c. stanowić podstawę wpisania $\mathrm{z}$ urzędu ostrzeżenia o niezgodności między stanem prawnym ujawnionym w księdze wieczystej a rzeczywistym stanem prawnym. Rozpoznając wniosek o wpis, sąd wieczystoksięgowy nie może bowiem pominąć treści dokumentów załączonych do wniosku (art. $626^{8} \$ 2$ K.p.c.) również wówczas, gdy treść ta jest sprzeczna z treścią księgi wieczystej ${ }^{36}$.

Należy zgodzić się ze stanowiskiem Sądu Najwyższego wyrażonym w uchwale z dnia 07 lipca 2011 r. $^{37}$, że ustalenie kręgu uczestników postępowania musi się

34 E. Gniewek, Księgi..., s. 789-790.

35 Postanowienie SN z dnia 31 stycznia 2017 r., I CSK 612/16, LEX nr 2254804.

36 E. Gniewek, Księgi..., s. 787-788.

37 Uchwała SN z dnia 7 lipca 2011 r., III CZP 45/2010, LEX nr 584620. 
mieścić $\mathrm{w}$ granicach kognicji sądu wieczystoksięgowego wynikających $\mathrm{z}$ art. $626^{8}$ $\$ 2$ K.p.c. To sprawia, że krąg uczestników postępowania sąd ustala w oparciu o treść księgi wieczystej, wniosku i załączonych do niego dokumentów ${ }^{38}$. Sąd wieczystoksięgowy nie ma obowiązku z urzędu badać prawdziwości wpisów w księdze wieczystej i samodzielnie poszukiwać ewentualnych uczestników postępowania wieczystoksięgowego ${ }^{39}$. Do jego kompetencji nie należy również ustalanie rzeczywistego właściciela nieruchomości, aby zawiadomić go o wpisie ${ }^{40}$.

Jednym z kluczowych zagadnień budzących wątpliwości powstałych na gruncie oceny przynależności podmiotów do kręgu uczestników postępowania wieczystoksięgowego jest okoliczność wystąpienia, najczęściej wskutek śmierci, następstwa prawnego po wnioskodawcy czy uczestniku postępowania. Chodzi o rozstrzygnięcie kwestii, czy następca prawny podmiotu, którego prawo ma zostać wykreślone, obciążone lub ujawnione w księdze wieczystej, staje się w myśl art. $626^{1}$ $\$ 2$ K.p.c. uczestnikiem postępowania wieczystoksięgowego. W takiej sytuacji trwające postępowanie wieczystoksięgowe powinno zostać zawieszone (art. 174 $\$ 1$ pkt 1 K.p.c. $w$ zw. $z$ art. $13 \$ 2$ K.p.c.), a następnie podjęte $z$ udziałem następcy prawnego (art. $180 \$ 1$ pkt $1 \mathrm{w}$ zW. $\mathrm{z}$ art. $13 \$ 2$ K.p.c.) ${ }^{41}$.

Większość przedstawicieli doktryny opowiada się za stanowiskiem, zgodnie z którym art. $626^{1} \$ 3$ K.p.c. wyłącza obowiązek zawieszenia postępowania wieczystoksięgowego w oparciu o art. $174 \$ 1$ pkt 1 i $\$ 2$ K.p.c. w przypadku śmierci uczestnika postępowania, jak również utraty przez niego zdolności sądowej. ${ }^{42}$ Nieco inne stanowisko zajmuje G. Jędrejek, który dopuszcza zawieszenie postępowania

38 J. Zawadzka, Ustawa..., s. 1168, zob. także postanowienie SN z dnia 9 stycznia 2008 r., II CZ 102/2007, LEX nr 1402611; postanowienie SN z dnia 20 stycznia 2011 r., I CSK 185/2010, LEX nr 848107; postanowienie SN z dnia 24 maja 2012 r., V CZ 16/2012, LEX nr 1214623; postanowienie SN z dnia 23 sierpnia 2012 r., II CSK 49/2012, LEX nr 1228586.

39 Także postanowienie SN z dnia 9 stycznia 2008 r., II CZ 102/2007, LEX nr 1402611; postanowienie SN z dnia 20 stycznia 2011 r., I CSK 185/2010, LEX nr 848107; postanowienie SN z dnia 24 maja 2012 r., V CZ 16/2012, LEX nr 1214623; postanowienie SN z dnia 23 sierpnia 2012 r., II CSK 49/2012, LEX nr 1228586.

40 E. Gniewek, Ksieggi..., s. 787-788.

41 Zob. M.Z. Sondej, Skutki śmierci wnioskodawcy albo uczestnika postępowania wieczystoksięgowego po złożeniu wniosku o wpis w kontekście zawieszenia postępowania z urzędu do czasu wstąienia do postępowania następców prawnych, 2019 [baza danych LEX], zob. także. P. Pruś, Kodeks..., s. 624.

42 P. Siciński, Zakres odpowiedniego stosowania w postępowaniu wieczystoksiegowym przepisów kodeksu postępowania cywilnego o procesie, Przegląd Sądowy 2004, nr 3, s. 96; P. Mysiak, Postępowanie..., s. 169-170; P. Mysiak, Wniosek o wpis w księdze wieczystej, Rejent 2008, nr 7-8, s. 96; P. Rylski, Uczestnik postępowania nieprocesowego - zagadnienia konstrukcyjne, Warszawa 2017, s. 393. 
wieczystoksięgowego na podstawie art. $626^{1} \S 3$ K.p.c. w przypadku śmierci uczestnika postępowania, po dokonaniu wpisu ${ }^{43}$.

Zagadnienie powyższe było przedmiotem zainteresowania Sądu Najwyższe$\mathrm{go}^{44}$, gdzie pomimo pewnych rozbieżności w orzecznictwie przeważało stanowisko o braku dopuszczalności zawieszenia postępowania wieczystoksięgowego na skutek śmierci uczestnika tego postępowania celem umożliwienia wstąpienia jego następcom prawnym. W uchwale w składzie siedmiu sędziów Sądu Najwyższego z dnia 28 listopada 2018 r. ${ }^{45}$ Sąd Najwyższy wyraźnie opowiedział się za poglądem, że: „W razie śmierci uczestnika postępowania wieczystoksięgowego sąd nie zawiesza postępowania”. Tym samym przyznał, że ograniczony krąg uczestników wyrażony w art. $626^{1} \S 2$ K.p.c służy przede wszystkim sprawnemu i szybkiego ujawnieniu zmiany stanu prawnego nieruchomości, nie zaś rozstrzyganiu sporu o prawo objęte wpisem ${ }^{46}$.

Prawo do sądu jest jednym $\mathrm{z}$ fundamentów funkcjonowania państwa, pełniąc funkcję gwarancyjną względem innych praw i wolności. Rozpoznając sprawę, sąd udziela ochrony prawnej podmiotowi występującemu z żądaniem rozstrzygnięcia określonego sporu. Każdy może zwrócić się do sądu, gdy żąda ustalenia swojego statusu prawnego i potwierdzenia ochrony prawnej ${ }^{47}$. W ten sposób realizowana jest podstawowa rola sądów, jakim jest wymierzanie sprawiedliwości ${ }^{48}$. W wyroku z dnia 7 września 2004 r. ${ }^{49}$ Trybunał Konstytucyjny uznał, że sprawy z zakresu

43 Por. G. Jędrejek, Zawieszenie postępowania wieczystoksięgowego w razie śmierci uczestnika, Studia Prawnicze KUL 2010, nr 2-3, s. 54 i nn.; J. Zawadzka, Przeglad orzecznictwa Izby Cywilnej Sądu Najwyższego. 2.3. Skutki śmierci uczestnika postępowania wieczystoksięgowego, Palestra 2019, nr 9, s. 109.

44 Uchwała SN z dnia 23 kwietnia 1985 r., III CZP 16/85, LEX nr 3099; postanowienie SN z dnia 16 czerwca 2004 r., I CZ 48/04, LEX nr 132562; postanowienie SN z dnia 9 stycznia 2008 r., II CZ 102/07, LEX nr 1402611; postanowienie SN z dnia 18 lutego 2009 r., I CZ 1/09, LEX nr 1353074; uchwała SN z dnia 7 lipca 2010 r., III CZP 45/10, LEX nr 584620; postanowienie SN z dnia 20 stycznia 2011 r., I CSK 185/10, LEX nr 848107; postanowienie SN z dnia 31 stycznia 2017 r., I CSK 612/16, LEX nr 2254804; postanowienie SN z dnia 28 lutego 2017 r., I CSK 133/16, LEX nr 2297405; postanowienie SN z dnia 12 maja 2017 r., III CSK 154/16, LEX nr 2312013; postanowienie SN z dnia 18 maja 2017 r., III CZ 18/17, LEX nr 231009.

45 Uchwała SN z dnia 28 listopada 2018 r., III CZP 25/18, LEX nr 2583384.

46 Wyrok TK z dnia 13 marca 1996 r., K 11/95, OTK ZU 1996, z. 2, poz. 9, a także wyrok TK z dnia 16 grudnia 2008 r., P 68/07, OTK ZU 2008, z. 10A, poz. 180.

47 A. Gajewska, Zasady niezawisłości sędziowskiej i niezależności sądów, w: Zasady ustroju III Rzeczpospolitej Polskiej, red. D. Dudek, Warszawa 2009, s. 245; P. Pogonowski, Prawo cywilne materialne i procesowe - dwa płuca jednego organizmu, w: Współczesne przemiany postępowania cywilnego, red. P. Pogonowski, P. Cioch, E. Gapska, J. Nowicka, Warszawa 2010, s. 256-257.

48 Por. K. Lubiński, Postępowanie wieczystoksięgowe w systemie postępowania cywilnego, w: Elektronizacja postępowania wieczystoksięgowego. Komentarz praktyczny. Akty wykonawcze, red. A. Marciniak, Warszawa 2016, s. 5-30. Wyrok TK z dnia 7 września 2004 r., P 4/04, OTK ZU 2004, z. 8A, poz. 81. 
postępowania wieczystoksięgowego powinny być zaliczane jako należące do spraw, o których mowa w art. 45 Konstytucji. Zakwalifikowanie spraw wieczystoksięgowych do spraw cywilnych w rozumieniu art. 1 K.p.c sprawia, że w ich wypadku standard postępowania jest kształtowany w oparciu o dostępność i rzetelność postępowania $^{50}$.

Kwestia wpływu art. $626^{1} \S 2$ K.p.c na zachowanie przestrzegania prawa do sądu w postępowaniu wieczystoksięgowym była przedmiotem rozważań Trybunału Konstytucyjnego w wyrokach z dnia 6 czerwca 2007 r. ${ }^{51}$ oraz z dnia 3 lipca 2007 r. ${ }^{52}$. Odpowiadając na zarzut, że komentowany przepis, ograniczając krąg uczestników postępowania w postępowaniu wieczystoksięgowym, narusza prawo do sprawiedliwego i jawnego rozpatrzenia sprawy oraz prawo do sądu, Trybunał Konstytucyjny wyjaśnił, że postępowanie wieczystoksięgowe nie stanowi sprawowania wymiaru sprawiedliwości. Do jego kompetencji nie należy rozstrzyganie sporu co do prawa, a jedynie służy ujawnieniu praw do nieruchomości i jako takim przyznaje ochronę. Wąski krąg uczestników występujących w postępowaniu wieczystoksięgowym $\mathrm{z}$ jednej strony oraz ograniczona kognicja sądu wieczystoksięgowego $\mathrm{z}$ drugiej mają na celu sprawne i szybkie ujawnienie zmiany stanu prawnego nieruchomości. W oparciu o wnioski płynące z tych orzeczeń Trybunał Konstytucyjny wyraził pogląd, że nie zostało naruszone prawo do sądu, gdyż osoby zainteresowane zawsze mają możliwość obrony swoich praw w postępowaniu o uzgodnienie treści księgi wieczystej z rzeczywistym stanem prawnym. Postępowanie z art. 10 u.k.w.h. zastało ukształtowane jako środek mający zapewnić bezpieczeństwo uczestnikom obrotu prawnego nieruchomościami ${ }^{53}$.

Rolą postępowania wieczystoksięgowego jest możliwie najszybsze ujawnienie w księdze wieczystej zmiany stanu prawnego nieruchomości. Wobec tego postępowanie wieczystoksięgowe zostało maksymalnie uproszczone w celu jego sprawnego przeprowadzenia. Zostało ono oparte na zasadzie wpisu uprzedniego, która kładzie nacisk na treść księgi wieczystej i dołączonych do wniosku dokumentów, stanowiących podstawę ochrony prawnej. Sprawy wieczystoksięgowe mają w większości przypadków charakter powtarzalny, a sprawy jednostkowe, gdzie pojawia się spór

50 B. Banaszak, P. Mysiak, Konstytucyjne..., s. 1243.

51 Wyrok TK z dnia 26 maja 2007 r., SK 29/05, OTK ZU 2007, z. 6A, poz. 54.

52 Wyrok TK z dnia 3 lipca 2007 r., SK 1/06, OTK ZU 2007, z. 7, poz. 73.

53 Zob. P. Mysiak, Ograniczenia kognicji sqdu wieczystoksięgowego w kontekście art. 45 ust. 1 Konstytucji Rzeczpospolitej Polskiej, w: Aktualne problemy konstytucji. Ksiega jubileuszowa z okazji 40-lecia pracy naukowej Profesora Bogusława Banaszaka, red. H. Babiuch, P. Kapusta, J. Michalska, Legnica 2017, s. 617-618; E. Kowalik, Zakres..., s. 208. 
co do prawa, winny być rozstrzygane w postępowaniu spornym, w którym nie ma ograniczenia co do kręgu jego uczestników czy kognicji sądu ${ }^{54}$.

Biorąc pod uwagę funkcję ewidencyjną i ochronną ksiąg wieczystych, należało znaleźć sposób rejestracji zmiany stanu prawnego nieruchomości. Zatem w przeważającej liczbie spraw ujawnienie zmiany stanu prawnego nieruchomości następuje w drodze postępowania wieczystoksięgowego, powództwo o usunięcie niezgodności między ujawnionym w księdze wieczystej stanem prawnym a rzeczywistym stanowi zaś swoiste dopełnienie postępowania wieczystoksięgowego. Należy zauważyć, że wpis w księdze wieczystej jest orzeczeniem, a co za tym idzie, korzysta z prawomocności materialnej. Pojawia się zatem problem, możliwość wystąpienia z powództwem z art. 10 u.k.w.h. narusza bowiem zasadę niewzruszalności i mocy wiążącej wpisu. Ustawodawca celem ochrony ważniejszego dobra, czyli prawa podmiotów, zapewnił osobom zainteresowanym możliwość ochrony na gruncie odrębnego postępowania, przełamując poniekąd zasadę prawomocności wpisów ${ }^{55}$. Na podstawie orzeczenia zapadłego w trybie art. 10 u.k.w.h. dokonuje się stosownych zmian w księdze wieczystej, porządkując stan prawny nieruchomości. Nie zmienia to faktu, że dopóki wpis jest w księdze wieczystej, dopóty korzysta on z przymiotu prawomocności i jako taki podlega ochronie ${ }^{56}$.

\section{Zakończenie}

Powyższe wywody prowadzą do wniosku, że art. $626^{1} \S 2$ K.p.c. wprowadzający ograniczony krąg uczestników postępowania wieczystoksięgowego wywiera przemożny wpływ na prawa i wolności jednostek uczestniczących w obrocie prawnym nieruchomości. Przyjęta wąska regulacja kręgu uczestników postępowania wieczystoksięgowego może w pewnych okolicznościach prowadzić do naruszenia przez dokonany wpis praw osób, które nie są uczestnikami postępowania wieczystoksięgowego. O ile stwierdzenie istnienia problemu w tym zakresie nie przysparza zasadniczo żadnych trudności, o tyle już znacznie cięższym gatunkowo zagadnieniem jest wskazanie na konkretne rozwiązania, które poprawią ten stan rzeczy. Należy zwrócić uwagę, że ze względu na ograniczoną kognicję sądu wieczystok-

54 H. Ciepła, E. Balan-Goncarz, Ustawa o ksieggach wieczystych. Komentarz. Wzory wniosków o wpis. Wzory wpisów do księgi wieczystej, Kraków 2007, s. 34-42; P. Mysiak, Ograniczenia..., s. 610; E. Gniewek, Księgi..., s. 789-790.

55 Postanowienie SN z dnia 8 marca 2007 r., III CSK 347/06, LEX nr 274213.

56 E. Kowalik, Zakres..., s. 207-210. 
sięgowego ochrona tych osób w postępowaniu wieczystoksięgowym nie w każdym wypadku mogłaby być skuteczna. Ponadto rolą postępowania wieczystoksięgowego nie jest ochrona praw podmiotowych. Skuteczne zabezpieczenie tych praw zapewnia powództwo o uzgodnienie stanu prawnego ujawnionego w księdze wieczystej z rzeczywistym stanem prawnym (art. 10 u.k.w.h.) lub możliwość np. uzyskania przez następcę prawnego zmarłego uczestnika ochrony jego praw w nowym postępowaniu o wpis w księdze wieczystej jego własnego prawa.

Ustawodawca wprowadzając ograniczony krąg uczestników postępowania wieczystoksięgowego oraz zawężając kognicję sądu w tym postępowaniu, zdecydował się na uproszczenie postępowania. Szybkie i sprawne ujawnienie poprzez wpis w księdze wieczystej zmiany stanu prawnego nieruchomości z punktu widzenia bezpieczeństwa obrotu prawnego nieruchomościami jest ważniejsze niż ewentualne straty w czasie spowodowane rozstrzyganiem sporów o prawo. Skomplikowany system ksiąg wieczystych bez wątpienia doprowadziłby do powstawania przewlekłości postępowań, co - biorąc pod uwagę liczbę rozpatrywanych spraw i rosnącą tendencję - negatywnie odbiłoby się na obrocie na rynku nieruchomości.

Wsparciem dla postępowania wieczystoksięgowego jest więc powództwo o uzgodnienie stanu prawnego ujawnionego $\mathrm{w}$ księdze wieczystej z rzeczywistym stanem prawnym, w którym sąd rozpoznający sprawę nie ma ograniczeń wynikających z art. $626^{1} \S 2$ K.p.c. Należy zgodzić się z przytaczanym już stwierdzeniem, że tak ukształtowany krąg uczestników postępowania wieczystoksięgowego nie narusza prawa do sądu, gdyż osoby zainteresowane zawsze mają możliwość obrony swoich praw w postępowaniu o uzgodnienie treści księgi wieczystej z rzeczywistym stanem prawnym. Myślę, że warto podkreślić wzajemne relacje i zależności pomiędzy tymi postępowaniami, z wyraźnym wspólnym uzupełnianiem się, aczkolwiek dalsze rozwinięcie tego zagadnienia znacznie przekroczyłoby ramy niniejszego opracowania.

\section{Bibliografia}

Banaszak B., Prawo konstytucyjne, Warszawa 2008.

Ciepła H., Balan-Goncarz E., Ustawa o księgach wieczystych. Komentarz. Wzory wniosków o wpis. Wzory wpisów do księgi wieczystej, Kraków 2007.

Czeszejko-Sochacki Z., Prawo do sądu w świetle Konstytucji Rzeczypospolitej Polskiej (Ogólna charakterystyka), Państwo i Prawo 1997, z. 11-12 (621-622).

Florczak-Wątor M., w: Konstytucja Rzeczpospolitej Polskiej. Komentarz, red. P. Tuleja, Warszawa 2019. 
Florczak-Wątor M., Prawo do sąu jako prawo jednostki $i$ jako gwarancja horyzontalnego działania praw i wolności, Przegląd Prawa Konstytucyjnego 2016, nr 3.

Gajewska A., Zasady niezawisłości sędziowskiej i niezależności sądów, w: Zasady ustroju III Rzeczpospolitej Polskiej, red. D. Dudek, Warszawa 2009.

GniewekE., Ksiegi wieczyste: art. 1-58 KWU, art. $626^{1}-626^{13}$ KPC. Komentarz, Warszawa 2018.

Gniewek E., Wnioskodawca i uczestnicy postępowanie wieczystoksiegowego, Rejent 2005, nr 9.

Grzegorczyk P., Weitz K., w: Konstytucja RP, t. 1. Komentarz do art. 1-86, red. M. Safian, L. Bosek, Warszawa 2016.

Jabłoński M., Jarosz-Żukowska S., Prawa człowieka i systemy ich ochrony. Zarys wykładu, Warszawa 2010.

Jefimko E., Postępowanie wieczystoksięgowe jako szczególny rodzaj postępowania nieprocesowego (zagadnienia wybrane), Przegląd Sądowy 2002, nr 10.

Jędrejek G., Zawieszenie postępowania wieczystoksięgowego w razie śmierci uczestnika, Studia Prawnicze KUL 2010, nr 2-3.

Korzan K., Zagadnienia dostosowania polskiego systemu postępowania cywilnego do standardów europejskich, Radca Prawny 1996, nr 5.

Kowalik E., Zakres kognicji sądu w postępowaniu wieczystoksięgowym, Warszawa 2020.

Kuropatwiński J., Księgi wieczyste: komentarz do art. $1-58^{2}$ u.k.w.h. oraz art. $626^{1}-626^{13}$ k.p.c., t. 1. Komentarz do art. 1-10 ustawy o ksiegach wieczystych i hipotece, Bydgoszcz 2013.

Lis-Staranowicz D., Konstytucyjne środki ochrony wolności i praw, w: Wolności i prawa człowieka w Konstytucji Rzeczypospolitej Polskiej, red. M. Chmaj, Warszawa 2016.

Lubiński K., Postępowanie wieczystoksięgowe w systemie postępowania cywilnego, w: Elektronizacja postępowania wieczystoksięgowego. Komentarz praktyczny. Akty wykonawcze, red. A. Marciniak, Warszawa 2016.

Łopalewski B., Krąg uczestników postępowania wieczystoksięgowego - w poszukiwaniu optymalnego modelu (uwagi de lage lata), Rejent 2012, nr 1.

Mysiak P., Ograniczenia kognicji sądu wieczystoksięgowego w kontekście art. 45 ust. 1 Konstytucji Rzeczpospolitej Polskiej, w: Aktualne problemy konstytucji. Ksiega jubileuszowa z okazji 40-lecia pracy naukowej Profesora Bogusława Banaszaka, red. H. Babiuch, P. Kapusta, J. Michalska, Legnica 2017.

Mysiak P., Podmioty postępowania wieczystoksięgowego, Rejent 2007, nr 4.

Mysiak P., Postępowanie wieczystoksięgowe, Warszawa 2012.

Mysiak P., Wniosek o wpis w księdze wieczystej, Rejent 2008, nr 7-8.

Nowakowski Z.K., Prawo rzeczowe. Zarys wykładu, Warszawa 1969.

Pietrzkowski H., Prawo do sądu (wybrane zagadnienia), Przegląd Sądowy 1999, nr 11-12.

Pogonowski P., Prawo cywilne materialne i procesowe - dwa płuca jednego organizmu, w: Współczesne przemiany postępowania cywilnego, red. P. Pogonowski, P. Cioch, E. Gapska, J. Nowicka, Warszawa 2010.

Pogonowski P., Realizacja prawa do sądu w postępowaniu cywilnym, Warszawa 2005.

Pruś P., w: Kodeks postępowania cywilnego. Komentarz, t. 2. Art. 506-1217, red. M. Manowska, Warszawa 2021.

Rylski P., Uczestnik postępowania nieprocesowego - zagadnienia konstrukcyjne, Warszawa 2017.

Rzewuski M., Glosa do uchwały SN z 7 lipca 2010 r., III CZP 45/10, Orzecznictwo Sądów Polskich 2011, z. 10, poz. 107. 
Sawczuk M., Konstytucyjne idee prawa sądowego cywilnego, w: Konstytucyjny ustrój państwa. Ksiegga jubileuszowa Profesora Wiesława Skrzydty, red. T. Bojarski, E. Gdulewicz, J. Szraniawski, Lublin 2000.

Siciński P., Zakres odpowiedniego stosowania w postępowaniu wieczystoksięgowym przepisów kodeksu postępowania cywilnego o procesie, Przegląd Sądowy 2004, nr 3.

Sondej M.Z., Skutki śmierci wnioskodawcy albo uczestnika postępowania wieczystoksięgowego po złożeniu wniosku o wpis $w$ kontekście zawieszenia postępowania $z$ urzędu do czasu wstąpienia do postępowania następców prawnych, 2019 [baza danych LEX].

Stawecki T., Rejestr nieruchomości, księgi hipoteczne, księgi wieczyste od czasów najdawniejszych do XXI wieku, Studia Iuridica 2002, $\mathrm{nr} 40$.

Szewczyk J., Krąg uczestników postępowania wieczystoksięgowego art. $626^{1} \$ 2$ k.p.c. Glosa do uchwały SN - Izby Cywilnej z 7 lipca 2010 r. (III CZP 45/10), Monitor Prawa Bankowego 2012, nr 3.

Tuleja P., w: Konstytucja Rzeczpospolitej Polskiej Komentarz, red. P. Tuleja, Warszawa 2019.

Zawadzka J., Przegląd orzecznictwa Izby Cywilnej Sądu Najwyższego. 2.3. Skutki śmierci uczestnika postępowania wieczystoksięgowego, Palestra 2019, $\mathrm{nr} 9$.

Zawadzka J., w: Ustawa o księgach wieczystych i hipotece. Postępowanie wieczystoksieggowe, red. J. Pisuliński, Warszawa 2014.

Żak M., Prawo do sądu jako element zasady dobrego rzadzenie w świetle orzecznictwa z zakresu praw człowieka, Palestra 2020, nr 2. 
